\title{
Organizational Justice and organizational citizenship behaviour
}

\author{
Sutikno M. ofar
}

\section{Introduction}

Organization own many employees with a variety of behaviors, one of them is OCB. Organizational Citizenship Behavior (OCB) is employees' work behavior that is discrete by not being recognized formally in the system, nevertheless, it has a purpose to promote the functions of the organization (Organ, 1988 in LePine, 2002). OCB is also an individual behavior that promotes the goals of the organization by contributing in the social and psychological environment (Smith, et al., 1983), and having their own particularities (Ariani, 2011).

OCB has a dimension that can be differentiated based on the targeted behavior that is OCBI which particularly directed to individual meanwhile OCBO is more directed to the organizations (Williams and Adreson, 1991). Konovsky and Organ (1996) and Podsakoff, et al. (2000) also divide OCB into five dimensions namely altruism, courtesy, conscientiousness, sportsmanship, and civic virtue. An organization runs through a predetermined system which applies to all employees, align with the level of consistency between the value of individual and the value in the organization felt by the employee. This alignment will affect the employee's expectations of his organization and will affect his perspective on the organization (Yan, et al., 2013). 


\section{Literature Review}

\section{Organizational Citizenship Behavior (OCB)}

Employees who are part of an organization must be assured to have positive behaviors that are expected, which will make employees do their work beyond the specified procedural limits. This behavior has been defined by Organ (1988) as an organizational citizenship behavior (Organizational Citizenship Behavior / OCB). This term was first to be thought out in 1983 by Organ, et al. (Smith, et al., 1983). They illustrate that OCB has two basic dimensions which are altruism and general compliance. The first dimension is altruism that aimed at certain individuals, where, if individuals have a problem and require help, then employees with altruistic behavior will work extra to help the other employees. The second dimension is general compliance, which is more about the existence of a sense of self-awareness by doing something right and exact but only for their own interests and not for others.

OCB is one of the important predictors in organizational learning (Ahmad \& Jameel,2020). OCB itself is discretionary of individual behavior or behavior which is not a requirement (job description), it indirectly recognized by the formal reward system, and it aggregately promotes the effective functioning of an organization, and Podsakoff, et al. (2000) stated that OCB improve the effectiveness of an organization. As the time goes, Konovsky and Organ (1996) and Podsakoff, et al.

\section{Impact of Organizational Justice}


An organization runs through a predetermined system which applies to all employees, align with the level of consistency between the value of individual and the value in the organization felt by the employee. This alignment will affect the employee's expectations of his organization and will affect his perspective on the organization (Jameel, Ahmad \& Mousa,2020). This perspective will affect employees in maximizing their working performance and naturally, employees will compare the workload and the results, as well as, each employee will evaluate their working situation by comparing cognitively their role and the results received from the organization as a reward/salary. Theoretically, this view is rooted in equity theory (Adams, 1965), where this theory also has a function as a measure of the sense of justice felt by an employee in an organization (Colquitt, 2001).

Greenberg and Cropanzano (2001) stated that organizational justice is the perception of employment justice in the organization. Cropanzano, et al., (2007) and (Gharan, Jameel \& Ahmad 2019) also reported that the employees who feel treated with justice will be more likely to position the organization positively and able to speak well to their friends who ignore and oppose them because they feel treated injustice. It is supported by (Karem, Jameel \& Ahmad, 2019). The justness procedure which is felt by the employees will influence their performance in doing the task and willing to help other employees in cooperation (Podsakoff, et al., 2000; Smith, et al., 1983 in Valentine, et al., 2011). An employee will have binding with the variation of an organization where this variation will be correlated in different ways to the attitude and behavior toward the organization (O'Reilly and Chatman, 1986). Besides, the individual will have psychologist binding to the purpose and values of the organization by showing the trust to each other (Jameel, Hamdi, Karem \& Ahmad,2020).

Distributive justice defined as fairness in the distribution of result or work allocation (Adams, 1965; Deutsch, 1975; Homans, 1961; Leventhal, 1976 in Colquitt, 2001). Greenberg (1990) stated that distributive justice is the employee 
assessment on the existence of justice in giving the appreciation and encouragement that they receive as the compensation of their contribution in the organization where they work, and able to predict the attitude that related directly with the result that has been done (Folger and Konovsky, 1989 in Moorman (1991).

Started from the research which is conducted by Homans in 1961, then Adams (1965), using a theoretical framework of social exchange, made an evaluation which shows the existence of justice. The research shows that an individual can react to the result of his or her work by comparing the amount of their work with several relevant works, and if that amount is a match then the individual will feel justice.

Interpersonal justice explained based on the sincerity and respect in performing communication between managers and employees and based on consideration of the respect and sensitivity of the employee itself (Colquitt, 2001). Besides, Greenberg (1993) argue that the existence of rules of respect and propriety is different from the rules of justification and truth, which resulted in giving name after interpersonal justice and the last with informational justice. The researchers argued that interactional justice can be obtained if the parties involved are able to communicate the details in the right procedure and the decisions that will be made are rectified by honesty and a piece of truthful information.

Meanwhile, the informational justice is the justice which focuses on giving an explanation to someone or a group of people by conveying information about a procedure that is used with the system and certain methods and how a result of the work is distributed (Colquitt, 2001). The explanation delivered are truthful and satisfactorily for decision making, and later it will refer to an explanation of a decision making. (Jameel, Ahmad \& Jwmaa,2020) wrote that informational justice explained the procedure for decisions making in a comprehensive and 
timely manner, which it will result in employees for being able to clearly understand what decisions they received at work.

\section{Research Model}

This research model connects the independent variables to the dependent variable and is moderated by moderating variables, the purpose is to strengthen or weaken the interaction between the independent variable and the dependent variable.

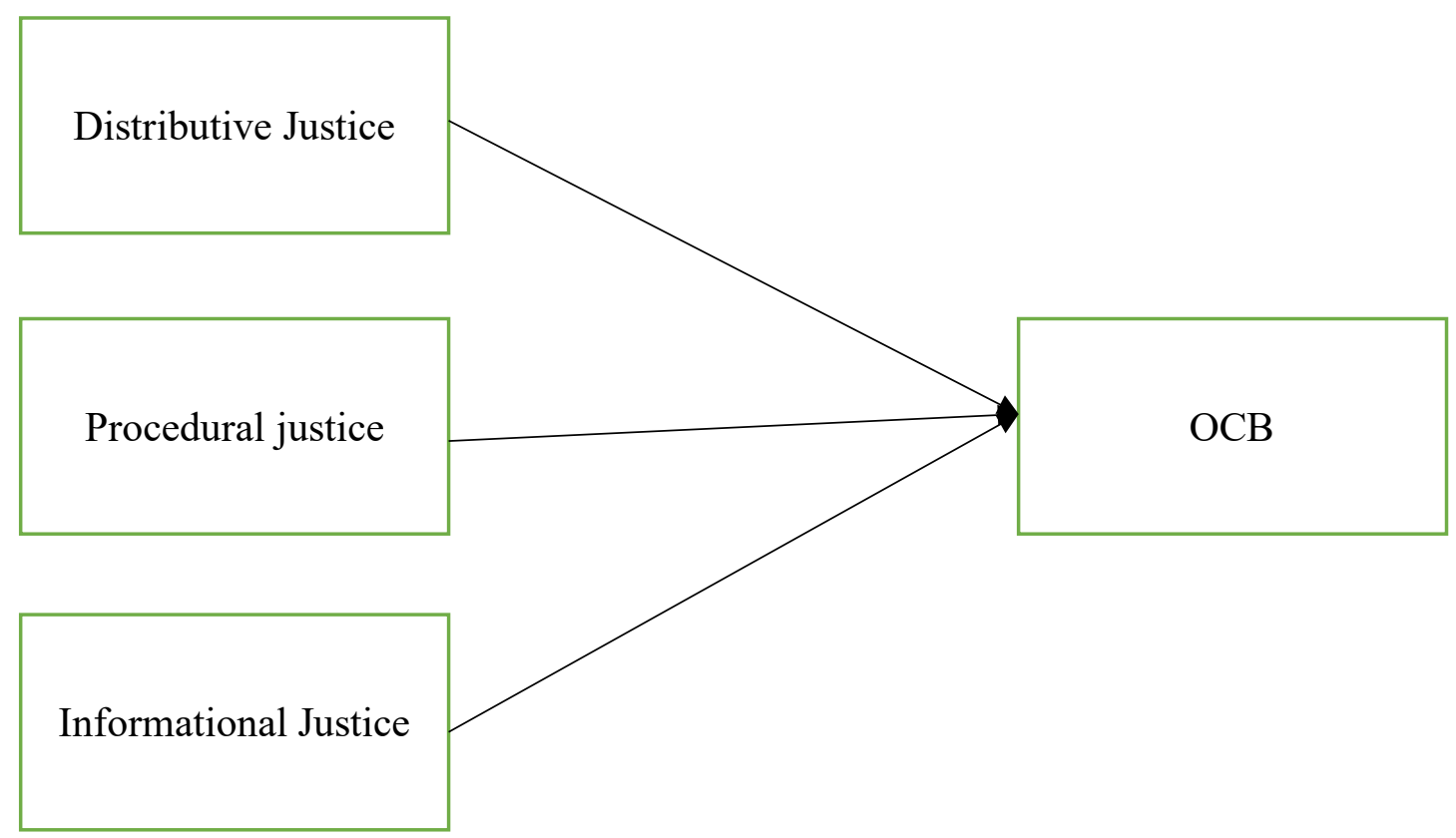

Figure 1. Framework

\section{Conclusion}

This research model will connect between Organizational justice variables, procedural justice, interpersonal justice, and informational justice towards organizational citizenship behaviour. This research will hopefully discover that 
distributive justice, procedural justice, interpersonal justice, and informational justice have an influence on OCB.

\section{Reference:}

Adams, JS. (1965). Inequity in social exchange. Press. http://web.mit.edu/curhan/www/docs/Articles/15341_Readings/Justice/InequityInSocialExch ange_Ad ams.pdf

Blau, PM. (1964). Exchange and Power in Social Life. Wiley, New York.

Carlo, G., Eisenberg, N., Troyer, D., Switzer, G and Speer, AL. (1991). The altruistic personality: In what contexts is it apparent? Journal of Personality and Social Psychology, 61.

Colquitt, JA and Rodell, JB. (2011). Justice, Trust, and Trustworthiness: A Longitudinal Analysis Integrating Three Theoretical Perspectives. Academy of Management Journal. Vol. 54.

Colquitt, JA and Shaw, JC. (2005). How should organizational justice be measured?. In J. Greenberg and J. A. Colquitt (Eds.), Handbook of organizational justice (pp. 113-152). Mahwah, NJ, US: Lawrence Erlbaum Associates Publishers.

Colquitt, JA. (2012). Organizational Justice. Organizational Psychology, Personality, and Social Psychology. DOI: 10.1093/oxfordhb/9780199928309.012.0016

Colquitt, JA. and Rodell, JB. (2015). Measuring Justice and Fairness. oxfordhb9780199981410- Cropanzano.indd.

Colquitt, JA., Conlon, D. E., Wesson, M.J., Porter, C.O.L.H. and K. Yee Ng. (2001). Justice at the Millennium: A Meta-Analytic Review of 25 Years of Organizational Justice Research. Journal of Applied Psychology, Vol. 86.

Jameel, A. S., Ahmad, A. R., \& Abdul-Karem, M. (2020, July). Organizational Justice and Performance among academic staff. In Proceedings of the 35th International Business Information Management Association Conference, IBIMA.

Greenberg, J. (1990). Employee Theft as a Reaction to Underpayment Inequity: The Hidden Cost of Pay Cuts. Journal of Applied Psychology, Vol. 75.

Konovsky, MA. and Organ, DW. (1996). Dispositional and contextual determinants of organizational citizenship behavior. Journal of Organizational Behavior, 17(3), 253-266. 
Jameel, A. S., Ahmad, A. R., \& Mousa, T. S. (2020). Organizational justice and job performance of academic staff at public universities in Iraq. Skyline Business Journal (2020), 16(1), 13-29.

Meyer, JP., Stanley, DJ., Herscovitch and Topolnytskty, L. (2002). Affective, continuance, and normative commitment to the organization: A Metaanalysis of antecedents, correlates, and consequences. Journal of Vocational Behavior, 61.

Organ, DW. (1988). Issues in organization and management series. Organizational citizenship behavior: The good soldier syndrome. Lexington, MA, England: Lexington Books/D. C.

Organ, DW. (1990). The Motivational Basis of Organizational Citizenship Behavior. Research in Organizational Behavior, Vol. 12. JAI Press Inc.

Organ, DW. and Paine, JB. (1999). A new kind of performance for industrial and organizational psychology: Recent contributions to the study of organizational citizenship behavior. In C. L. Cooper andI.T.Robertson (Eds.), International review of industrial and organizational psychology.

Jameel, A. S., Mahmood, Y. N., \& J Jwmaa, S. (2020). Organizational justice and organizational commitment among secondary school teachers.

Ghran, L. A. Z., Jameel, A. S., \& Ahmad, A. R. (2019). The effect of organizational justice on job satisfaction among secondary school teachers. International Review, 3(4), 84-93.

Karem, M. A., Jameel, A. S., \& Ahmad, A. R. (2019). The impact of organizational justice dimensions on organizational commitment among bank employees. International Journal of Psychosocial Rehabilitation, 23(02), 502-513.

Ahmad, A. R., \& Jameel, A. S. (2020). Job satisfaction as a mediator between transformational leadership and organizational citizenship behaviours. International Journal of Advanced Science and Technology, 29(05), 10163-10174.

Jameel, A. S., Hamdi, S. S., Abdul-Karem, M., \& Ahmad, A. R. (2020). Organizational justice and job satisfaction among nurses. UKH Journal of Social Sciences, 4(2), 61-69.

Salam, A. (2020). Organizational justice as a predictor of organizational citizenship behaviour. International Business Education Journal, 13. 
